\title{
Rediscovery of Dendropsophus tintinnabulum (Anura: Hylidae) in the upper Rio Negro Drainage (Amazonas, Brazil), with a description of its advertisement call and external morphology
}

\author{
Bernardo Franco da Veiga Teixeira ${ }^{1,2}$ and Ariovaldo Antonio Giaretta ${ }^{1}$ \\ ${ }^{1}$ Laboratório de Taxonomia, Sistemática e Ecologia Comportamental de Anuros Neotropicais, Faculdade de Ciências Integradas \\ do Pontal, Universidade Federal de Uberlândia, Rua 20, 1.600, Bairro Tupã, 38304-402, Ituiutaba, MG, Brazil. \\ ${ }^{2}$ Programa de Pós-graduação em Biologia Comparada, Universidade de São Paulo, Departamento de Biologia/FFCLRP, \\ Avenida dos Bandeirantes, 3900, 14040-901, Ribeirão Preto, SP, Brazil. E-mail: teixeirabfv@gmail.com.
}

\begin{abstract}
Rediscovery of Dendropsophus tintinnabulum (Anura: Hylidae) in the upper Rio Negro Drainage (Amazonas, Brazil), with a description of its advertisement call and external morphology. Dendropsophus tintinnabulum is one of six species of the genus unassigned to any group. Voucher specimens and recordings of this taxon obtained during field work in the municipality of São Gabriel da Cachoeira and elsewhere in the district of Cucuí in Amazonas state, Brazil, permit a description of the advertisement call and external morphological features. Based on overall similarities in size, dorsal color, body shape, advertisement call, and preliminary genomic results, D. tintinnabulum is tentatively assigned to the D. microcephalus Group.
\end{abstract}

Keywords: Amazon, bioacoustics, Dendropsophus microcephalus Group.

\begin{abstract}
Resumo
Redescoberta de Dendropsophus tintinnabulum (Anura: Hylidae) na bacia do Alto Rio Negro (Amazonas, Brasil) com a descrição do canto de anúncio e da morfologia externa. Dendropsophus tintinnabulum é uma das seis espécies de Dendropsophus que ainda não foi atribuída a nenhum dos grupos de espécies atualmente aceitos. Espécimes-testemunhos e gravações desse táxon obtidos durante trabalho de campo no município de São Gabriel da Cachoeira e no distrito de Cucuí, estado do Amazonas, Brasil, permitem a descrição do canto de anúncio e de caracteres da morfologia externa. A partir de todas as similaridades em relação ao tamanho corporal, padrão de coloração, formato do corpo, canto e dados genômicos preliminares, alocamos tentativamente $D$. tintinnabulum no grupo de D. microcephalus.
\end{abstract}

Palavras-chave: Amazônia, bioacústica, grupo de Dendropsophus microcephalus.

Received 20 January 2016

Accepted 16 May 2016

Distributed December 2016 


\section{Introduction}

As presently defined, the genus Dendropsophus Fitzinger, 1843 comprises almost 100 species placed in nine species groups (Faivovich et al. 2005) and six species unassigned to any group. One of these species, D. tintinnabulum (Melin, 1941), was described from northern Brazil based on collections from field expeditions to tropical regions of South America during the years 1923-1926. Since then, the species rarely has been reported in the literature (Lutz 1973, Azevedo-Ramos and Galatti 2002). During a field trip in the upper Rio Negro, we collected and recorded individuals of Dendropsophus that we assigned to D. tintinnabulum based on the original description and area of occurrence. Herein, 65 years after the original description, we describe the advertisement call and external morphological features based on recently collected examples of this poorly known Amazonian species.

\section{Materials and Methods}

Fieldwork was conducted in the municipality of São Gabriel da Cachoeira $\left(0^{\circ} 09^{\prime} 43^{\prime \prime} \mathrm{S}\right.$, 66 59'32" W; $79 \mathrm{~m}$ a.s.l.; 27 June 2014) and elsewhere in the district of Cucuí $\left(1^{\circ} 11^{\prime} 55^{\prime \prime} \mathrm{S}\right.$, $66^{\circ} 50^{\prime} 13^{\prime \prime} \mathrm{W} ; 88 \mathrm{~m}$ a.s.1.; 29 June 2014) in Amazonas state, Brazil.

Calls were recorded with a digital recorder (Marantz PMD 671) at a $48.0 \mathrm{kHz}$ sampling rate and a 16-bit resolution (mono WAVE format file) coupled to a directional microphone (Sennheiser K6/ME67). Acoustic variables were analyzed using Raven Pro 1.5 for Windows from The Cornell Lab of Ornithology (Bioacoustic Research Program 2012); settings were Hann window function at FFT width 1024 samples, 3 $\mathrm{dB}$ filter bandwidth $244 \mathrm{~Hz}$, overlap (locked) $85 \%$, and DFT size (locked) 1,024 samples. All other settings followed the "default" of Raven Pro. Terminology of the call descriptions follows that of Duellman and Trueb (1994). Dominant frequency was obtained using the function "Peak frequency." Pulse repetition rate was quantified as the number of pulses divided by note duration.
Sound figures were obtained in the Seewave package (Version 1.5.9) (Sueur et al. 2008), R (Version 2.12.1) platform (R Development Core Team 2014), using Hanning window function, $85 \%$ overlap, and 256 points resolution (FFT).

Specimens were euthanized in 5\% lidocaine, fixed in $10 \%$ formalin and preserved in $70 \%$ ethanol, and identified based on Melin's (1941) description of Dendropsophus tintinnabulum. Measurements were made with an ocular micrometer coupled to a stereomicroscope, and those greater than $10 \mathrm{~mm}$ were taken with calipers accurate to $0.1 \mathrm{~mm}$. Nine measurements follow those defined by Duellman (1970): snoutvent length (SVL), head length (HL), head width (HW), tympanum diameter (TD), eye diameter (ED), interorbital distance (IOD), internarial distance (IND), shank length (SL) (= tibia length), and foot length (FL) and two measurements are those of Heyer et al. (1990) thigh length (TL) and hand length (HAL). Eyenostril distance (END) is as defined by Napoli and Caramaschi (1998).

Specimens examined and recordings along with the voucher specimens (Appendix I) are in the collection of frogs of the Universidade Federal de Uberlândia (AAG-UFU), Uberlândia municipality, Minas Gerais state, Brazil. Additional specimens examined are deposited in the following zoological collections: Museu de Zoologia da Universidade de São Paulo, São Paulo (MZUSP), and Museu Nacional, Universidade Federal do Rio de Janeiro, Rio de Janeiro (MNRJ), Brazil. We were unable to obtain data for the three syntypes of D. tintinnabulum at Museum of Natural History of Gothenburg, Sweden. Preliminary results based on genetic data are not presented here because a phylogenetic study has been undertaken by another research group.

\section{Results}

\section{Species Identification}

The series of frogs from the municipality of São Gabriel da Cachoeira and its environs in the 

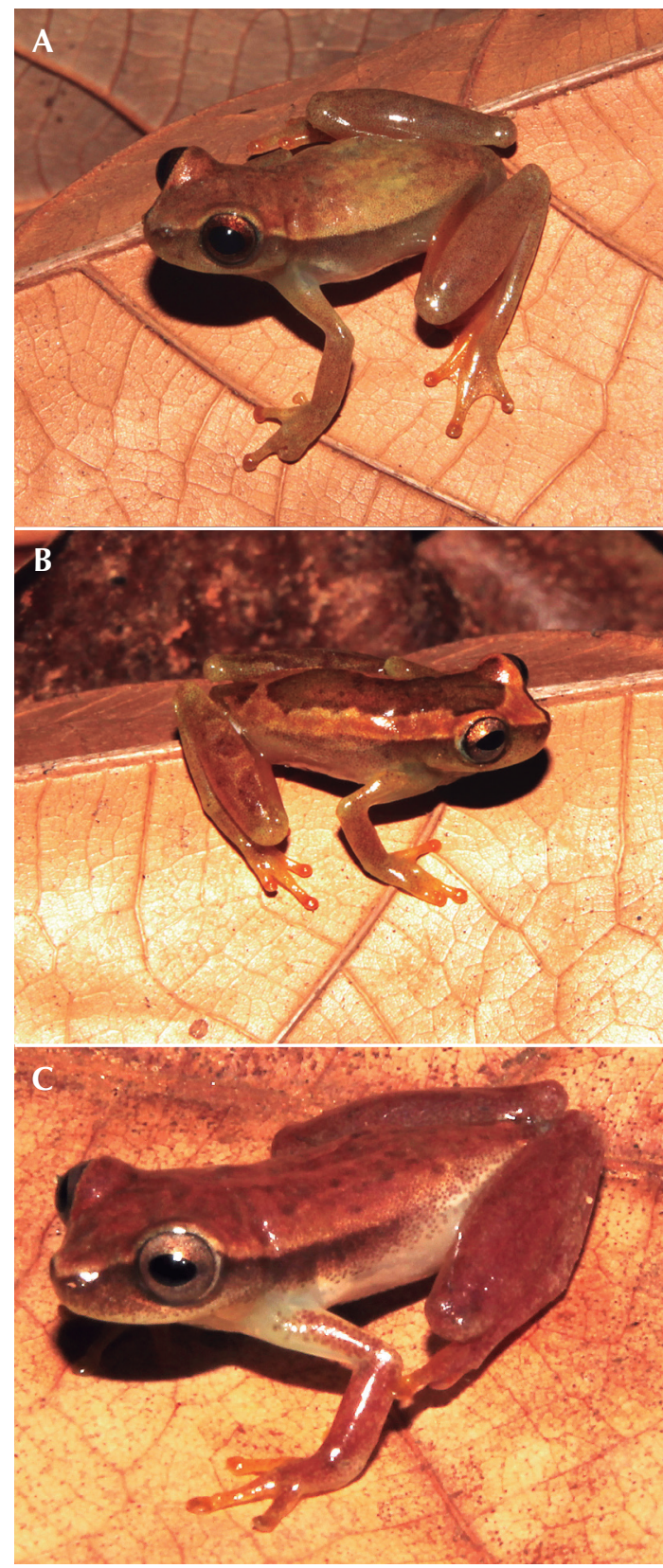

Figure 1. Dendropsophus tintinnabulum from the municipality of São Gabriel da Cachoeira, Amazonas state, Brazil. (A) AAG-UFU 3883; SVL = $17.4 \mathrm{~mm}$; (B) AAG-UFU 3884; SVL $=19.2$ $\mathrm{mm} ;$ (C) AAG-UFU 3854; SVL = $18.4 \mathrm{~mm}$ (voucher). district of Cucuí was assigned to D. tintinnabulum based on the following combination of characters: snout-vent length ranging from 16.4-19.2 mm (Table 1); head broader than body, vomerine teeth barely visible; snout triangular to rounded; large eyes, protruding beyond lateral sides of head; tympanum discretely visible; a small knob is present at the mandibular symphysis; prepollical tubercle large; slight, elliptical medial metatarsal tubercle, and lateral tubercle and tarsal fold absent. Skin smooth; belly and medial parts of thighs granular; axillary fold distinct; single and subgular vocal sac, yellowish orange; dorsal color in life varying from yellowish orange to greenish brown; dorsal color pattern varying from immaculate to possessing irregularly distributed brown dots; some frogs with broad stripe between eyes and along dorsum; dots variably present on shanks; toes and fingers orange; diffuse brown broad band along dorsolateral limits of body extending from the snout tip toward sacral region, upper edged by a light-colored stripe (Figures 1,2).

\section{Advertisement Call of Dendropsophus tintinnabulum ( $\mathrm{N}=3$ recorded males $)$}

The advertisement call (Figure 3) consists of one type of note with a pulsed structure emitted in groups (series) or isolated (mean: 1.35 notes per call; range: $1-4$ notes; $\mathrm{SD}=0.13 ; N=60$ ). Average call parameters are as follow: note duration, $16 \mathrm{~ms}$ (range: $10-21 \mathrm{~ms} ; \mathrm{SD}=1.7 ; N=$ 80 ); number of pulses/note, 3 (range: $2-4 ; \mathrm{SD}=$ $3.2 ; N=78$ ); pulse duration, $5.5 \mathrm{~ms}$ (range: 3.0 10.0; $\mathrm{SD}=0.5 ; N=47$ ); pulse repetition rate, 188.9 pulses/s (range: $133.3-266.7 ; \mathrm{SD}=11.4 ; N$ =78); and note repetition rate (within a series), 7.0 notes/s (range: $5.3-8.4 ; \mathrm{SD}=0.5 ; N=15$ ); inter-note interval in series of notes, $229 \mathrm{~ms}$ (range: 206-263; $\mathrm{SD}=4 ; N=20$ ); and dominant frequency, $5691 \mathrm{~Hz}$ (range: 5343-5906; $\mathrm{SD}=$ $56.8 ; N=82$ ). A weak frequency peak occurs at about $12 \mathrm{kHz}$ ( 2 of 3 males) and a third peak with relevant energy is present ( 2 of 3 males) in 17033 Hz (range: $16688-17344 ; \mathrm{SD}=195.1 ; N=38$ ). Individual values are presented in Table2. 
Table 1. Morphometric variables of Dendropsophus tintinnabulum ( $N=8$ males) from municipality of São Gabriel da Cachoeira, Amazonas state, Brazil.

\begin{tabular}{lcc}
\hline & Mean \pm SD & Range \\
\hline Snout-vent length & $17.9 \pm 0.8$ & $16.4-19.2$ \\
Head length & $5.7 \pm 0.2$ & $5.5-5.9$ \\
Head width & $6.7 \pm 0.3$ & $6.0-7.0$ \\
Interorbital distance & $2.1 \pm 0.2$ & $1.7-2.5$ \\
Internarial distance & $1.3 \pm 0.2$ & $1.1-1.6$ \\
Eye-nostril distance & $1.4 \pm 0.1$ & $1.2-1.5$ \\
Eye diameter & $2.2 \pm 0.1$ & $2.1-2.5$ \\
Tympanum diameter & $1.0 \pm 0.1$ & $0.8-1.2$ \\
Thigh length & $9.7 \pm 0.6$ & $8.5-10.5$ \\
Shank length & $9.9 \pm 0.5$ & $9.0-10.8$ \\
Hand length & $5.2 \pm 0.4$ & $4.7-6.0$ \\
Foot length & $8.0 \pm 0.8$ & $7.1-9.7$ \\
\hline
\end{tabular}
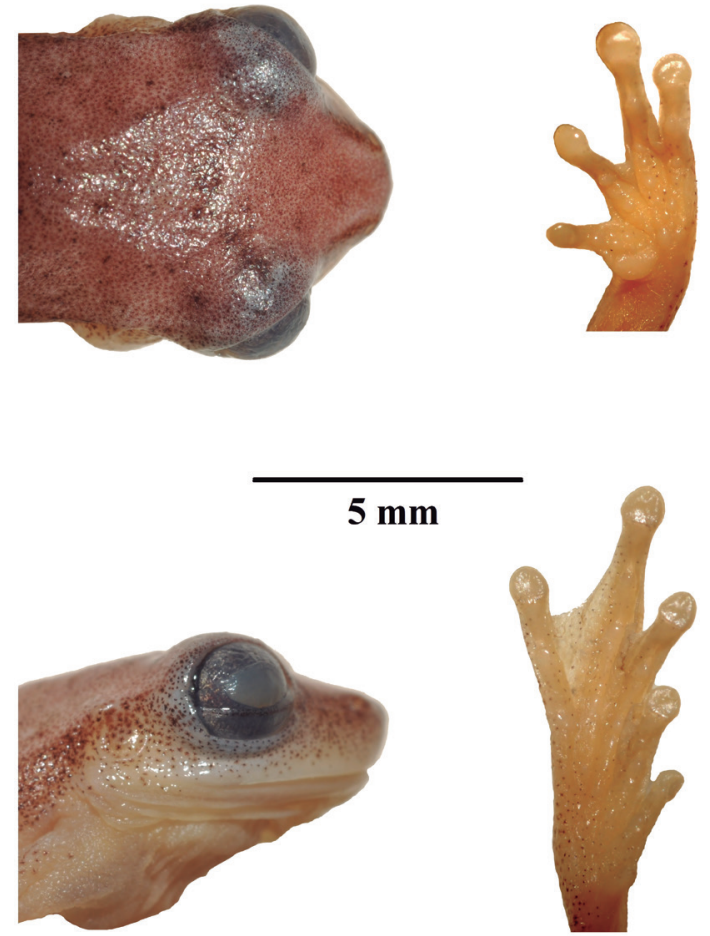

Figure 2. Dendropsophus tintinnabulum (AAG-UFU 3883), adult male from the municipality of São Gabriel da Cachoeira, Amazonas state, Brazil. Lateral and dorsal views of the head and palmar and plantar views of hand and foot, respectively.
Male Dendropsophus tintinnabulum call from perches on herbaceous vegetation $0.2-1.0$ $\mathrm{m}$ above the ground along the river margins (Rio Negro), typically in "Igapó" flooded-forest environments. Syntopic species include Scinax cruentommus (Duellman, 1972), Hypsiboas boans (Linnaeus, 1758), H. cinerascens (Spix, 1824), Leptodactylus validus Garman, 1888, Rhinella marina (Linnaeus, 1758), Rhinella sp. (R. margaritifera group), and Scinax ruber (Laurenti, 1798).

\section{Discussion}

The combination of snout-vent length, body shape, dorsal color patterns, and the large, prominent eyes of Dendropsophus tintinnabulum is most similar to this suite of characters in the Amazonian species of the D. microcephalus Group (i.e., D. leali [Bokermann, 1964]; D. juliani Moravec, Aparicio and Köhler, 2006; D. reichlei Moravec, Aparicio and Köhler, 2008; D. riveroi [Cochran and Goin, 1970]; and D. coffea Köhler, Jungfer, and Reichle, 2005). Based on these resemblances, the advertisement call, and the preliminary genetic analysis of $D$. 

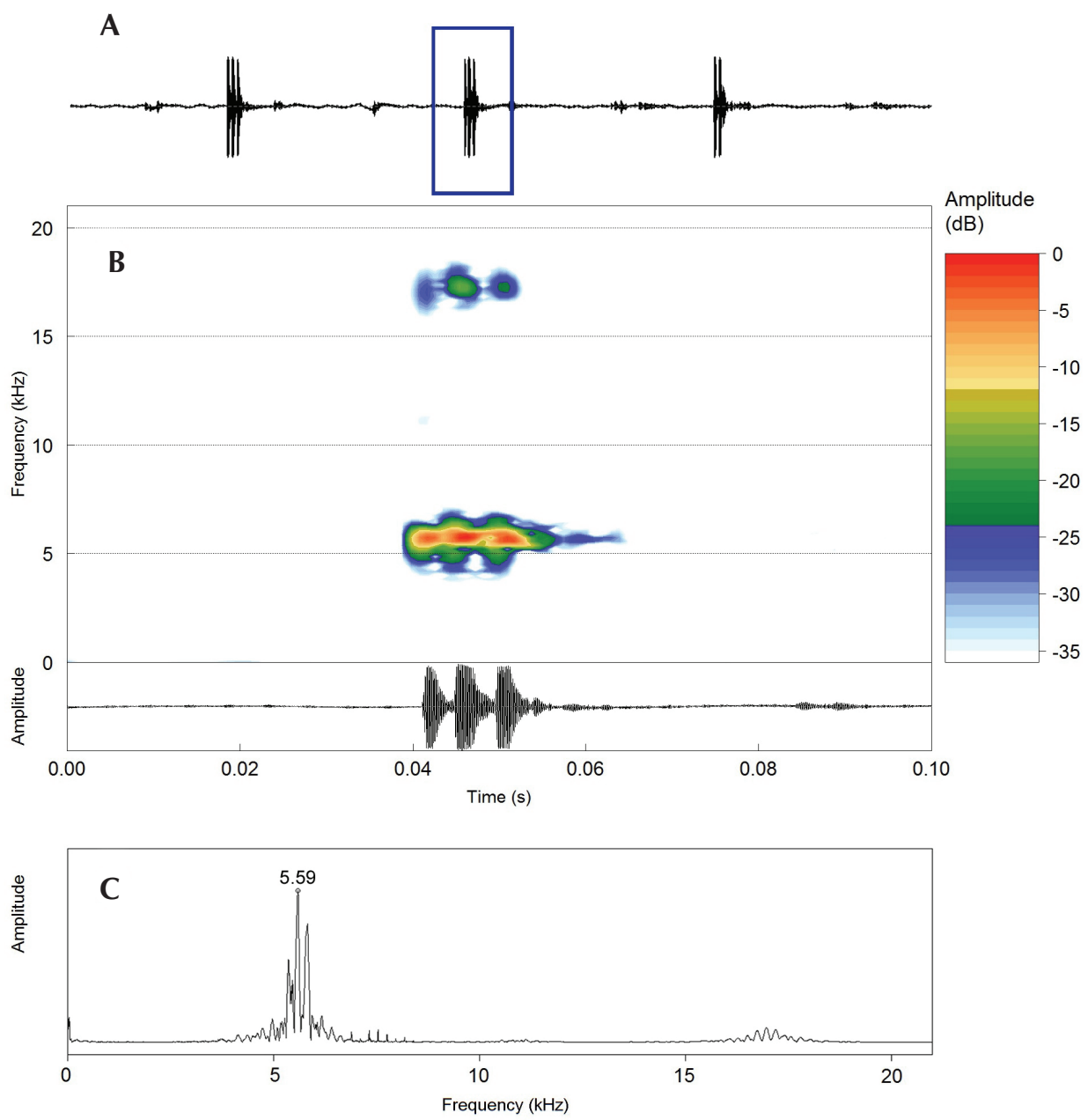

Figure 3. Advertisement call of Dendropsophus tintinnabulum from the municipality of São Gabriel da Cachoeira, Amazonas state, Brazil. Note the remarkably strong harmonic ( ${ }^{\text {rd }}$ harmonic) that is about $17 \mathrm{kHz}$. (A) Waveform of a call sequence (1.8 s section); the note outlined is detailed in (B), along with its waveform, and $(\mathbf{C})$ power spectrum. Sound file: Dendrop_tintinnabSaoGabrielAM1aTRC_AAGm671. Air temperature $30^{\circ} \mathrm{C}$.

tintinnabulum, we tentatively assign D. tintinnabulum to the D. microcephalus Group.

Dendropsophus tintinnabulum differs morphologically from the other Amazonian members of the D. microcephalus Group as follows ( $D$. tintinnabulum in brackets): D. shiwiarum Ortega-Andrade and Ron, 2013 and D. ozzyi Orrico, Peloso, Sturaro, Silva-Filho, Neckel-
Oliveira, Gordo, Faivovich, and Haddad, 2014 have pointed fingers discs (rounded in $D$. tintinnabulum); $D$. juliani has a green vocal sac (Moravec et al. 2006) (yellowish orange); D. reichlei has one or two small, white to cream spots below the eye (Moravec et al. 2008); and D. microcephalus (Cope, 1886), D. nanus (Boulenger, 1889), and D. walfordi (Bokermann, 
Table 2. Advertisement call of Dendropsophus tintinnabulum specimens from São Grabriel da Cachoeira, Amazonas state, Brazil. Mean \pm SD (range) [number of analyzed calls].

\begin{tabular}{|c|c|c|c|}
\hline Traits & $\begin{array}{l}\text { AAG-UFU } 3856 \\
(\mathrm{SVL}=17.5 \mathrm{~mm})\end{array}$ & $\begin{array}{l}\text { AAG-UFU } 3857 \\
(\mathrm{SVL}=17.7 \mathrm{~mm})\end{array}$ & $\begin{array}{l}\text { AAG-UFU } 3854 \\
(\mathrm{SVL}=\mathbf{1 8 . 4} \mathbf{~ m m})\end{array}$ \\
\hline Note duration (ms) & $17.5 \pm 2.1(13.0-21.0)[20]$ & $16.1 \pm 1.6(12.0-19.0)[40]$ & $\begin{array}{c}14.2 \pm 2.4 \\
(10.0-19.0)[20]\end{array}$ \\
\hline Pulse duration (ms) & $17.5 \pm 2.1(13.0-21.0)[16]$ & $17.5 \pm 2.1(13.0-21.0)[16]$ & $17.5 \pm 2.1(13.0-21.0)[15]$ \\
\hline $\begin{array}{l}\text { Number of pulses } \\
\text { per note }\end{array}$ & $5.9 \pm 1.7(5.0-10.0)[16]$ & $4.9 \pm 0.9(4.0-7.0)[16]$ & $5.6 \pm 1.4(3.0-9.0)[15]$ \\
\hline Peak frequency $(\mathrm{Hz})$ & $\begin{array}{c}5770 \pm 79.7 \\
(5625-5906)[20]\end{array}$ & $\begin{array}{c}5639 \pm 91.6 \\
(5343-5765)[41]\end{array}$ & $5665 \pm 91.6(5390-5906)$ \\
\hline Third harmonic (Hz) & $\begin{array}{c}17228 \pm 71.8 \\
(17109-17344)[20]\end{array}$ & $\begin{array}{c}16839 \pm 85.0 \\
(16688-17016)[18]\end{array}$ & Not detected \\
\hline Pulse repetition rate & $\begin{array}{c}184.2 \pm 21.0 \\
(157.9-230.7)[20]\end{array}$ & $\begin{array}{c}201.8 \pm 28.3 \\
(157.9-266.7)[38]\end{array}$ & $\begin{array}{c}180.6 \pm 22.2 \\
(133.3-230.8)[20]\end{array}$ \\
\hline $\begin{array}{l}\text { Call group rate } \\
\text { (notes per s) }\end{array}$ & $6.9 \pm 0.8(6.1-8.0)[3]$ & $7.6 \pm 0.6(6.3-8.4)[8]$ & $6.6 \pm 1.2(5.3-7.8)[4]$ \\
\hline $\begin{array}{l}\text { Number of notes } \\
\text { per call }\end{array}$ & $1.3 \pm 0.6(1.0-3.0)[16]$ & $1.3 \pm 0.5(1.0-3.0)[30]$ & $1.5 \pm 0.9(1.0-4.0)[14]$ \\
\hline $\begin{array}{l}\text { Number of notes } \\
\text { per sequence }\end{array}$ & $2.3 \pm 0.5(2.0-3.0)[3]$ & $2.1 \pm 0.3(2.0-3.0)[8]$ & $2.8 \pm 0.8(2.0-4.0)[4]$ \\
\hline $\begin{array}{l}\text { Internote interval in } \\
\text { series (s) }\end{array}$ & $0.23 \pm 0.19(0.21-0.26)[4]$ & $0.22 \pm 0.01(0.20-0.25)[9]$ & $\begin{array}{c}0.23 \pm 0.01 \\
(0.22-0.24)[7]\end{array}$ \\
\hline
\end{tabular}

1962) have numerous dotted lines on dorsum (dots irregularly distributed). We did not find any reliable qualitative morphological differences between D. leali, D. coffea, D. riveroi, and D. tintinnabulum.

Acoustically, Dendropsophus tintinnabulum can be distinguished from the other Amazonian species of the D. microcephalus Group that have advertisement calls composed of one type of note. Dendropsophus juliani has a lower dominant frequency (dominant frequency 3300 $4400 \mathrm{~Hz}$ vs. $5484-5812 \mathrm{~Hz}$ in D. tintinnabulum; Moravec et al. 2006). Dendropsophus ozzyi has a higher dominant frequency $(9130-10136 \mathrm{~Hz}$; Orrico et al. 2014). The note duration in other species of the group are as follow: D. reichlei, 68-112 ms (Moravec et al. 2008); $38 \mathrm{~ms}$ in D. walfordi (De la Riva et al. 1997); $53 \mathrm{~ms}$ in $D$. shiwiarum (Ortega-Andrade and Ron 2013); 34 $92 \mathrm{~ms}$ in D. leali (Marquez et al. 1993); 20-29 ms in D. riveroi (Marquez et al. 1993); and 60-116 ms in D. coffea (Köhler et al. 2005). The note duration is10-21 ms in D. tintinnabulum.

In comparison with the species that occur in the adjacent biomes, the advertisement call of Dendropsophus tintinnabulum is most like those of D. cachimbo (Napoli and Caramaschi, 1999), D. cruzi (Pombal and Bastos, 1998), and D. pseudomeridianus (Cruz, Caramaschi, and Dias, 2000). In D. tintinnabulum, the dominant frequency $(5484-5812 \mathrm{~Hz})$ is higher than in $D$. cachimbo (3890-4406 Hz; Teixeira and Giaretta 2015). The note duration of $D$. tintinnabulum (10-21 ms) longer than in D. cruzi (7-9 ms; Pombal and Bastos 1998). Although there is an overlap in ranges of call values between $D$. tintinnabulum and D. pseudomeridianus, the former has a lower mean of pulse repetition rate (189 pulses/s) than D. pseudomeridianus (477 pulses/s; Caram et al. 2014). 
Dendropsophus tintinnabulum was described from Uaupés River (“some days' journey north of Ipanoré”, Melin 1941 page 29). Our record from Cucuí extends the distribution of the species to the upper Rio Negro to the Brazilian/ Venezuelan/Colombian borders, around $200 \mathrm{~km}$ northeast of the type locality (Appendix I). Dendropsophus tintinnabulum probably has a wider distribution along the Rio Negro Drainage. Perhaps our data will be helpful in the assessment of additional distributional records for this Amazonian frog species.

\section{Acknowledgments}

Financial support was granted by $\mathrm{CNPq}$ and FAPEMIG. A research grant was conceded by CNPq to AAG. Doctoral fellowship was conceded by CAPES to BFVT. We are grateful to Thiago R. de Carvalho by help with the fieldwork and sharing audio recordings. Osmar Cordeiro, Odimar Cordeiro, and their families that provided invaluable assistance and logistics in the village of Cucuí. Access to the indigenous communities was facilitated by FOIRN (Federação das Organizações Indígenas do Rio Negro) and FUNAI/SGC (Fundação Nacional do Índio/São Gabriel da Cachoeira). Collection permit was issued by ICMBio/SISBIO (30059-5).

\section{References}

Azevedo-Ramos, C. and U. Galatti. 2002. Patterns of amphibian diversity in Brazilian Amazonia: conservation implications. Biological Conservation 103: 103-111.

Bioacustic Research Program. 2012. Raven Pro: Interactive Sound Analisys Software. Version 1.5. URL: http:// www.birds.cornell.edu/raven

Caram, J., C. Luna-Dias, F. Hepp, and S. P. Carvalho-eSilva. 2014. The advertisement call of Dendropsophus pseudomeridianus (Cruz, Caramaschi \& Dias) (Anura: Hylidae). Zootaxa 3784: 294-296.

De la Riva, I., R. Márquez, and J. Bosch. 1997. Description of the advertisement calls of some South American Hylidae (Amphibia, Anura): taxonomic and methodological consequences. Bonner Zoologische Beiträge 47: $175-185$.
Duellman, W. E. 1970. The Hylid Frogs of Middle America. Lawrence. Monographs of the Museum of Natural History. University of Kansas. 473 pp.

Duellman, W. E. and L. Trueb (eds.). 1994. Biology of Amphibians. Baltimore. The John Hopkins University Press. 670 pp.

Faivovich, J., C. F. B. Haddad, P. C. A. Garcia, D. R. Frost, J. A. Campbell, and W. C. Wheeler. 2005. Systematic review of the frog family Hylidae, with special reference to Hylinae: phylogenetic analysis and taxonomic revision. Bulletin of the American Museum of Natural History 294: 1-240.

Heyer, W. R., A. S. Rand, C. A. Cruz, O. L. Peixoto, and C. E. Nelson. 1990. Frogs of Boracéia. Arquivos de Zoologia 31: 231-410.

Köhler, J., K. H. Jungfer, and S. Reichle. 2005. Another new species of small Hyla (Anura, Hylidae) from Amazonian sub-Andean forest of western Bolivia. Journal of Herpetology 39: 43-50.

Lutz, B. 1973. Brazilian Species of Hyla. Austin. University of Texas Press. 265 pp.

Marquez, R., I. De la Riva, and J. Bosch. 1993. Advertisement calls of Bolivian species of Hyla (Amphibia, Anura, Hylidae). Biotropica 25: 426-443.

Melin, D. 1941. Contributions to the knowledge of the Amphibia of South America. Göteborgs Kungliga Vetenskaps-och Vitterhets-Samhälles Handlingar Följd, Series B 1: 1-71.

Moravec, J., J. Aparicio, and J. Köhler. 2006. A new species of tree frog, genus Dendropsophus (Anura: Hylidae), from the Amazon of northern Bolivia. Zootaxa 1327: 23-40.

Moravec, J., J. Aparicio, M. Guerrero-Reinhard, G. Calderon, and J. Köhler. 2008. Diversity of small Amazonian Dendropsophus (Anura: Hylidae): another new species from northern Bolivia. Zootaxa 1918: 1-12.

Napoli, M. F. and U. Caramaschi. 1998. Duas novas espécies de Hyla Laurenti, 1768 do Brasil central afins de $H$. tritaeniata Bokermann, 1965 (Amphibia, Anura, Hylidae). Boletim do Museu Nacional, Nova Série, Zoologia 391: 1-12.

Orrico V. G. D., P. L. V. Peloso, M. J. Sturaro, H. F. SilvaFilho, S. Neckel-Oliveira, M. Gordo, J. Faivovich, and C. F. B. Haddad. 2014. A new "bat-voiced" species of Dendropsophus Fitzinger, 1843 (Anura, Hylidae) from the Amazon basin, Brazil. Zootaxa 3881: 341-361. 
Ortega-Andrade, H. M. and S. R. Ron. 2013. A new species of small tree frog, genus Dendropsophus (Anura: Hylidae) from the eastern Amazon lowlands of Ecuador. Zootaxa 3652: 163-178.

Pombal Jr., J. P. and R. P. Bastos. 1998. Nova espécie de Hyla Laurenti, 1768 do centro-oeste brasileiro e a posição taxonômica de Hyla microcephala werneri Cochran, 1952 e $H$. microcephala meridiana B. Lutz, 1952 (Anura, Hylidae). Boletim do Museu Nacional 390: $1-14$

R Development Core Team. 2014. R Foundation for Statistical Computing. Version 3.1.0. URL: http:// www.R-project.org
Sueur, J., T. Aubin, and C. Simonis. 2008. Seewave: a free modular tool for sound analysis and synthesis. Bioacoustics 18: 213-226.

Teixeira, B. F. V. and A. A. Giaretta. 2015. Setting a fundament for taxonomy: advertisement calls from the type localities of three species of the Dendropsophus rubicundulus group (Anura: Hylidae). Salamandra 51: $137-146$.

Editor: Jaime Bertoluci

Appendix I. Specimens examined.

Dendropsophus tintinnabulum: BRAZIL: Amazonas: São Gabriel da Cachoeira: AAG-UFU 3854-3857, Distrito de Cucuí 3882-3884; Taracuá: MZUSP 118212-118213.

Dendropsophus leali: type specimens: MZUSP 74210 (Ex. WCAB 10397); MZUSP 74483-74486 (EX. WCAB 10379, 10388, 10390, 10394).

Dendropsophus riveroi: COLOMBIA: AmAzonAS: Leticia MZUSP 95883-95886 (Ex. WCAB 11751-11754) (Topotypes).

Dendropsophus cruzi: type specimens: MNRJ 21782; GOIÁS: Silvânia: AAG-UFU 1987-1990 (Topotypes).

Dendropsophus walfordi: type series: MZUSP 73652 (Ex. WCAB 8436); MZUSP 74019-74041; topotype specimens: AAG-UFU 5306-5327.

Appendix II. AAG-UFU collection voucher number and labels of the related analyzed sound files.

\begin{tabular}{lc}
\hline Voucher number & Sound file labels \\
\hline 3856 & Dendrop_tintinnabSaoGabrielAM1aTRC_AAGm671 \\
3857 & Dendrop_tintinnabSaoGabrielAM2TRC_AAGm671 \\
3854 & Dendropsophus_tintinnabulum_SaoGrabrielDaCachoeira_AM_1b_BFVT_AAG_m671 \\
\hline
\end{tabular}

